\title{
INVESTIGATIONS INTO THE MAJOR CAUSAL AGENT OF RINDSPOT ON LEMONS
}

\author{
L.E. JAMIESON ${ }^{1}$, A. HARTY ${ }^{2}$, D. ZIVKOVIC-BRADY ${ }^{2}$, \\ R.A. FULLERTON ${ }^{1}$ and P. RAMANKUTTY ${ }^{1}$ \\ ${ }^{1}$ HortResearch, Private Bag 92169, Auckland, New Zealand \\ ${ }^{2}$ Kerifresh Ltd, Waipapa Rd, Kerikeri, New Zealand
}

Corresponding author: ljamieson@hortresearch.co.nz

\begin{abstract}
Rindspot has been an increasing problem for producers of lemons over the last 3-5 years. The damage is a form of oleocellosis, caused by peel oil released after the rupture of an oil gland. In severe cases up to $60 \%$ of the crop can have rindspot. To identify the primary cause of the problem, lemons with rindspot were analysed for evidence of insects or pathogens. Fungi associated with rindspot were those that are common inhabitants of the skin and leaves of citrus and were not considered to be causing rindspot. A high proportion of affected lemons collected in March had remnants of Lepidopteran larvae associated with the spots. Lemons bagged with citrus flower moth (Prays nephelomima) had significantly more rindspots than lemons bagged with no insects, other insects or unbagged lemons. Trees sprayed with insecticides had fewer lemons with rindspots and fewer citrus flower moths infesting flowers.

Keywords: citrus flower moth, Prays nephelomima, rindspot, lemon damage, pathogens.
\end{abstract}

\section{INTRODUCTION}

Rindspot has become a significant problem for New Zealand lemon producers over the last 3-5 years because damaged fruit are rejected for market. It also occurs on some mandarin varieties. The disorder can appear on fruit over a range of sizes including fruit as small as $2-3 \mathrm{~cm}$ diameter. Rindspot results from damage caused to rind cells by peel oil released after the rupturing of an oil gland (oleocellosis). The first symptoms of rindspot are dark brown or black depressed lesions between conspicuous oil glands. There is usually a small 'crater', which is the remnants of the ruptured oil gland, in the centre of the scab. The damaged superficial tissues dry out, and, as the fruit expands, it forms a thin cracked superficial scab on the surface of the fruit.

Rindspot is prevalent in Kerikeri, Auckland and Bay of Plenty in New Zealand. It has also been recorded in Gisborne but is not as common as in the more northern citrus growing areas. Lemons in New Zealand tend to produce multiple crops throughout the year and there tends to be a low incidence of rindspot occurring on each crop. However, the incidence of rindspotting increases in late summer so that in some orchards rindspot can affect up to $60 \%$ of the crop over the period March-May (fruit originating from the October/November flowering).

Rindspotting has been observed to be more severe after high rainfall, suggesting that water penetrating the outer surface of the fruit may cause excess turgidity in the rind making the oil glands more prone to rupturing. Oleocellosis is normally associated with abrasion, rough handling or other physical injuries, with wet weather predisposing the rind to oleocellosis (Wardoski 1989; Anon. 2006). The use of gibberellic acid and calcium nitrate as rind-strengthening agents to prevent rindspot on Encore mandarin has previously been investigated in New Zealand with no success (Pyle et al. 2002). 
A lower incidence of rindspotted fruit has been reported from trials where fruit have been bagged or dipped in a kaolin clay particle barrier (Pyle et al. 2002). This may have been a result of shielding the fruit from moisture (rain/dew), pathogens or insects. In California, leafhoppers cause rindspot on citrus by puncturing the surface to feed and thereby rupturing an oil gland (Grafton-Cardwell et al. 2003). Citrus thrips can cause similar damage when laying eggs in the epidermis of the rind of fruit. In New Zealand rindspots have occasionally been found associated with armoured scale insects, and it is possible that the newly settled juveniles may occasionally rupture oil glands when inserting their mouthparts into the skin to feed. Other factors such as nutritional deficiency and chemical applications have also been suggested as contributing factors to rindspot (Pyle et al. 2002).

It is impossible to identify control measures to reduce the incidence of rindspot without knowing the causal agent. An investigation to determine whether insects or pathogens could be the major causal agent on lemons in New Zealand was therefore carried out.

\section{METHODS}

\section{Insects and pathogens associated with rindspot}

A sample of 70 lemons with rindspot was randomly collected from each of three Auckland and two Kerikeri lemon orchards on 3-4 occasions from October 2004 to April 2005. Twenty fruit were examined under the microscope and rindspots dissected. The presence of insects and mites associated with rindspot was recorded. The number of rindspots per fruit and associated holes or remnants of insects was also recorded. The remaining 50 lemons were placed in vented containers and held for 4-6 weeks to determine whether insects would emerge from any eggs that may have been laid on the fruit.

Additional samples of 10-40 lemons from four orchards were examined for pathogens by binocular microscope. The surfaces of the spots and surrounding skin were surface sterilised by swabbing with $95 \%$ ethanol and small fragments of skin from the margins of 'active' lesions, where the margin was still apparently spreading, were plated onto potato dextrose agar modified with ampicillin and streptomycin to inhibit bacterial growth. Plates were incubated for five days and examined for the presence of fungi.

\section{Insecticide trial one}

At a lemon orchard in Kerikeri, trees from two rows (ca 80 trees) were not sprayed with insecticides from 1 November 2004 until 18 April 2005. Trees in another four rows (ca 160 trees) had acephate/mineral oil (Lancer ${ }^{\circledR} 750 \mathrm{DF}$ at $2 \mathrm{~kg} / \mathrm{ha}$ and DC-Tron at 10 litres/ha) applied on 12 February 2005 and abamectin/mineral oil (Avid ${ }^{\circledR}$ at $500 \mathrm{ml} / \mathrm{ha}$ and DC-Tron 10 litres/ha) applied on 22 March 2005. On 22 April 2005, 20 fruit from randomly chosen trees in the nil-insecticide rows were inspected and the number of rindspots counted. A similar number of fruit on insecticide-treated trees was also assessed.

\section{Inclusion trial one}

Seven treatments were applied to each of five nil-insecticide trees in insecticide trial one. The details of the treatments are shown in Table 1. Insects were caged over clusters of five or more immature lemons ranging in size from 8 to $30 \mathrm{~mm}$ long using terylene bags fastened to the stem below the fruit with a twist tie. Each tree was a replicate and contained all of the seven treatments. Insects were either collected from colonies maintained at HortResearch, Mt Albert, Auckland, or collected from other lemon trees at the same orchard. Bagged fruit with no added insects served as a control. Fruit in other clusters were pricked 8-10 times with a pin and bagged as a positive (physical injury) control. On 26 April 2005 the treated clusters of fruit were removed and stored at $18^{\circ} \mathrm{C}$ until assessment of the number of rindspots per fruit 1-2 days later. Remnants of insects associated with rindspots were also recorded. 
TABLE 1: The seven treatments that were applied to lemon trees that had not been sprayed with insecticides in an orchard at Kerikeri.

\begin{tabular}{lccc}
\hline Treatment & Source of insects & $\begin{array}{c}\text { Approx. no. } \\
\text { per bag }\end{array}$ & $\begin{array}{c}\text { Date of } \\
\text { bagging }\end{array}$ \\
\hline $\begin{array}{l}\text { Bagged control } \\
\text { Pricked and bagged control }\end{array}$ & - & - & 18.2 .05 \\
$\begin{array}{l}\text { Mealybugs } \\
\text { Pseudococcus longispinus) }\end{array}$ & Mt Albert colony & $50-100$ & 18.2 .05 \\
$\begin{array}{l}\text { Cicada (Amphipsalta } \\
\text { zelandica and A. cingulata) }\end{array}$ & Field collected & 2 & 18.2 .05 \\
$\begin{array}{l}\text { Latania scale } \\
\text { (Hemiberlesia lataniae) }\end{array}$ & Mt Albert colony & $50-100$ & 7.3 .05 \\
$\begin{array}{l}\text { Citrus flower moth } \\
\text { (Prays nephelomima) }\end{array}$ & Field collected & $10-20$ & 7.3 .05 \\
$\begin{array}{l}\text { Aphids } \\
\text { (Toxoptera citricida) }\end{array}$ & Field collected & $20-50$ & 7.3 .05 \\
\hline
\end{tabular}

\section{Insecticide trial two}

At the same lemon orchard in Kerikeri two treatments (insecticide and nil-insecticide) were applied to blocks of 193-240 trees. Acephate (Lancer ${ }^{\circledR} 750 \mathrm{DF}$ at $2 \mathrm{~kg} / \mathrm{ha}$ ) was applied on 17 January 2006, maldison (Malathion 50 EC at 4 litres/ha) on 10 February 2006 and spinosad/surfactant (Success Naturalyte at $800 \mathrm{ml} / \mathrm{ha}$ and Contact Low Foam at $500 \mathrm{ml} / \mathrm{ha}$ ) on 22 February 2006. Treatments were replicated three times. Three delta pheromone traps loaded with $300 \mathrm{ug}$ of the sex pheromone of citrus flower moth ((Z)-7-tetradecenal) (Gibb et al. 2005) were placed ca $1.5 \mathrm{~m}$ high in the canopy of three randomly selected trees within each treatment plot. These traps were maintained from November 2005 to April 2006. The sticky bases were removed weekly, refrigerated and sent to HortResearch for identification and counting of citrus flower moths. Data were presented as males caught per trap per day. Pheromone lures were replaced every 6 weeks.

On 12 January, 15 February and 9 March 2006, 20 individual fruit or flowers were examined and the number of rindspots and number of flowers infested with citrus flower moths (by presence of insect or webbing or frass) were recorded on each of 10 trees. In addition, 50 flowers from five randomly selected trees (and neighboring trees if flowers were absent) were collected and placed in plastic pottles with gauze ventilation in lids and bases. The samples were stored at $21^{\circ} \mathrm{C}$ and numbers of emerged moths recorded 4-6 weeks later.

\section{Inclusion trial two}

On 27 January 2006, flowers infested with citrus flower moths were collected from an organic orchard in Kerikeri and placed in fine mesh terylene bags. On five randomly selected trees within the nil-insecticide plots in insecticide trial two, two bags with 50 infested flowers were placed over fruiting shoots to cover at least three green lemons (fruit ca 15-30 cm long) per bag. Similar fruit clusters were enclosed by bags without insects. After 6 weeks ( 9 March 2006), shoots with bags were removed, stored at $18^{\circ} \mathrm{C}$ and numbers of rindspots per fruit counted 1-2 days later. The number of rindspots and remnants of insects (with and without a rindspot beneath) on bagged fruit were compared with the number on unbagged fruit in situ (10 fruit per tree).

\section{Statistical analysis}

The analysis of the pheromone trap catch data is a repeated measures study in which the response of male citrus flower moths was measured on 19 consecutive occasions. This results in a correlation between the initial readings and subsequent ones for the response. Repeated measures analysis adjusts for this correlation when determining the treatment effects. 
For analysis of data from lemons collected in the insecticide trials a mixed model was fitted to (1) the proportion of fruit with rindspot, (2) the proportion of infested floral parts, (3) the average number of rindspot per 20 fruit sample, and (4) the numbers of emerged moths, with treatment as fixed effect and tree within plot within block as random effects. The data for each date were analysed separately. Prior to analysis, the proportion data were transformed using the angular transformation, while the average number of rindspot per 20 fruit sample and the numbers of emerged moths were transformed using the logarithmic transformation.

For the inclusion trials, a mixed model was fitted to the average rindspots per fruit with treatment as the fixed effect and fruit cluster within tree within block as the random effects. The data were transformed prior to analysis using the logarithmic transformation.

All analysis was performed using Genstat Release 8.2 (Lawes Agricultural Trust, Rothamsted Experimental Station, UK). The models assume that the error terms are normally and independently distributed with zero mean and constant variances. Model adequacy checks were performed by examining histograms, normal probability plots and scatter plots of the residuals.

\section{RESULTS}

\section{Insects and pathogens associated with rindspot}

Live insects that were frequently found associated with rindspots were mealybug, aphids, predatory mites, Tyrophagus mites and Tarsonemus mites. Occasionally greenhouse thrips (Heliothrips haemorrhoidalis) and Kelly's citrus thrips (Pezothrips kellyanus) were also found. These insects are common inhabitants of lemons that show no rindspot and are not considered to be associated with the damage. In February 2005, cicadas were abundant in the orchards and cicada pupal moults were sometimes found on fruit. Occasionally a rindspot was found under some of the tarsi ('feet') of the moult. In November 2004, six Lepidopteran larvae were found feeding on rindspotted lemons collected from one orchard in Auckland in October 2004. The larvae were reared through to adults and identified by Landcare Research as Capua intractana, a tortricid moth whose larvae feed on dead plant material. Eggs of this moth are laid in batches of 5-20 overlapping scale-like eggs. No eggs resembling $C$. intractana eggs were found on fruit in further collections and no moths of any species were observed emerging from lemons kept for 4-5 weeks. The species was disregarded as a potential cause of rindspot.

Approximately 23-68\% of rindspots on lemons collected from the Auckland orchards in March 2005 had very small head capsules of a neonate Lepidopteran (moth) larva in a hole below a fine semi-transparent membrane on the surface of the lesion. Some head capsules had a dead larval body attached. A total of 99 out of 218 rindspots examined in March had these Lepidopteran larval remains. All of these very small first instar larvae were dead suggesting that the rupturing of the oil gland had killed them.

Fungi that were isolated from lemons at the four orchards were Colletotrichum gloeosporioides (the most frequently isolated fungus), Phomopsis sp., Epicoccum sp., Phoma sp, Fusarium sp, Penicillium sp and Cladosporium sp. Colletotrichum gloeosporioides was also recovered from epidermal tissue of healthy skin. All of these fungi are common inhabitants of the skin and leaves of citrus (Agrios 1997; Timmer et al. 2003) and are not thought to be a causal agent of rindspot.

\section{Insecticide and insect inclusion trial one}

Those trees that had insecticides applied to them had fewer fruit with rindspots compared with trees that did not have insecticides applied (Table 2). Insecticide treated fruit also had fewer rindspots than insecticide 'free' fruit, indicating that an insect may have been contributing to the higher incidence of rindspot in that trial.

Young fruit that had been bagged with citrus flower moth had significantly $(\mathrm{P}=0.012)$ more rindspots (19 per lemon) than fruit caged with other insects (0.6-2.8 per lemon) and no insects (1.7 per fruit). Those fruit that had been physically injured with a pin prior to bagging had ca 4.9 rindspots per fruit and was not significantly different from the number of rindspots on fruit bagged with CFM, other insects or no insects. Some of 
TABLE 2: Mean number of rindspots per fruit and mean percentage of fruit with rindspots in insecticide-treated trees and trees without insecticides applied.

\begin{tabular}{lcc}
\hline Treatment & $\begin{array}{c}\text { Mean \% fruit with } \\
\text { rindspots } \pm \text { SEM }\end{array}$ & $\begin{array}{c}\text { Mean no. rindspots per fruit } \\
\pm \text { SEM (min-max) }\end{array}$ \\
\hline Insecticide & $36.3 \pm 3.4 \mathrm{~b}^{1}$ & $0.63 \pm 0.07$ b $(0-10)$ \\
Nil-insecticide & $71.5 \pm 3.0 \mathrm{a}$ & $2.67 \pm 0.25$ a $(0-27)$ \\
\hline
\end{tabular}

${ }^{1}$ Means within a column with different letters are statistically different $(\mathrm{P}<0.05)$.

the pricks made by pin did not rupture an oil gland, therefore did not result in a rindspot. Lemons caged with latania scale each had 10-20 first instars that had settled on the rind and none of these were associated with rindspots. Between 28 and $72 \%$ of fruit naturally aborted in the bags and most of these were ca $10 \mathrm{~mm}$ long. These preliminary results indicate that fruit larger than $10 \mathrm{~mm}$ should be used in future bagging trials to avoid such a high proportion of fruit drop.

\section{Insecticide trial two}

The flight activity of male citrus flower moths in insecticide and nil-insecticide plots is shown in Figure 1. For the numbers of moths caught per trap per day, only the main effect of date was significant $(\mathrm{P}<0.001)$ and there was no main effect of treatment $(\mathrm{P}=0.410)$. Similar numbers of moths were trapped in insecticide and nil-insecticide plots both before spray applications (total 4140 and 4987 moths, respectively) and after spray applications began (total 20817 and 22211, respectively). At peak flight activity from 14 February to 2 March only $16 \%$ fewer moths were caught in the insecticide plots than the nil-insecticide plots (total 8824 and 10505, respectively).

Before spray applications there was no difference between the degree of citrus flower moth infestation in flowers or the level of rindspot in insecticide and nil-insecticide plots (Table 3). However, 8 weeks after the first insecticide was applied there were significantly more citrus flower moths infesting flowers, and more rindspotting in nil-insecticide plots than insecticide treated plots.

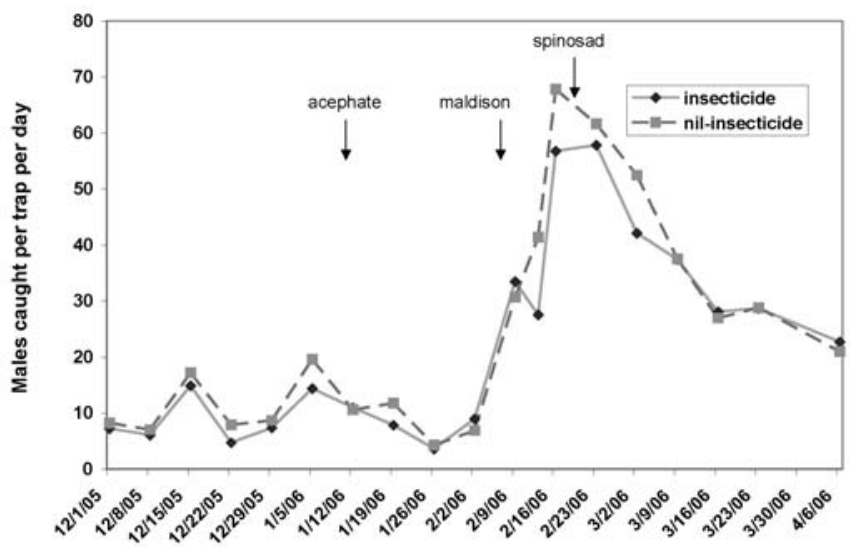

FIGURE 1: Mean number of male citrus flower moths caught per trap per day from November 2005-April 2006 in traps located in insecticide treated and nil-insecticide blocks of a lemon orchard. Dates of the spray applications are indicated. 
TABLE 3: Mean number of rindspots per fruit, percentage of fruit with rindspot, percentage of flowers infested with citrus flower moths and number of citrus flower moths emerged per 50 flowers on insecticide and nilinsecticide lemon trees.

\begin{tabular}{|c|c|c|c|c|}
\hline Treatment & $\begin{array}{l}\text { Mean no. } \\
\text { rindspots per } \\
\text { fruit }\end{array}$ & $\begin{array}{l}\text { Mean \% fruit } \\
\text { with rindspot }\end{array}$ & $\begin{array}{c}\text { Mean } \% \text { flowers } \\
\text { infested with } \\
\text { moths }\end{array}$ & $\begin{array}{l}\text { No. moths } \\
\text { emerged per } \\
50 \text { flowers }\end{array}$ \\
\hline \multicolumn{5}{|c|}{ Pre treatment $(\mathbf{1 2 . 0 1 . 0 6 )}$} \\
\hline Insecticide & $0.55 \pm 0.10$ & $34.33 \pm 6.69$ & $43.00 \pm 9.76$ & $11.93 \pm 3.37$ \\
\hline Nil-insecticide & $0.49 \pm 0.01$ & $26.50 \pm 1.00$ & $44.33 \pm 4.57$ & $14.07 \pm 1.33$ \\
\hline P-value & 0.603 & 0.361 & 0.633 & 0.349 \\
\hline \multicolumn{5}{|c|}{ Five weeks after treatment $(15.02 .06)$} \\
\hline Insecticide & $0.52 \pm 0.06$ & $28.17 \pm 2.33$ & $38.17 \pm 2.73$ & $13.53 \pm 2.49$ \\
\hline Nil-insecticide & $1.80 \pm 0.13$ & $70.50 \pm 1.44$ & $63.33 \pm 6.42$ & $27.53 \pm 4.61$ \\
\hline $\mathrm{P}$-value & 0.009 & 0.004 & 0.135 & 0.107 \\
\hline \multicolumn{5}{|c|}{ Eight weeks after treatment $(09.03 .06)$} \\
\hline Insecticide & $0.82 \pm 0.07$ & $33.67 \pm 2.95$ & $-^{1}$ & $20.33 \pm 2.91$ \\
\hline Nil-insecticide & $2.24 \pm 0.43$ & $73.50 \pm 0.43$ & - & $61.20 \pm 2.60$ \\
\hline P-value & 0.008 & 0.016 & - & 0.001 \\
\hline
\end{tabular}

${ }^{1}$ Not enough flowers were present in plots to carry out flower assessments on

9 March 2006.

\section{Inclusion trial two}

Fruit bagged with citrus flower moths had significantly more rindspots than lemons bagged without citrus flower moths or unbagged fruit (Table 4). On each rindspot on fruit bagged with citrus flower moth there was an egg membrane usually with a hole into the fruit and remnants of a neonate larva in the hole. However, there were also egg membranes present on the fruit bagged with citrus flower moths with no rindspot beneath (Table 4). These were thought to be either unhatched or non-viable eggs.

TABLE 4: Mean number of rindspots (most with egg membranes) per fruit and egg membranes not associated with rindspots on fruit bagged with and without citrus flower moth (CFM) and unbagged fruit.

Treatment

Mean no. of rindspots Mean no. of egg membranes

\begin{tabular}{lrlc}
\hline Bagged with CFM & $12.43 \pm 1.23$ & $\mathrm{a}^{1}$ & $17.39 \pm 7.31$ \\
Bagged without CFM & $0.82 \pm 0.06$ & $\mathrm{c}$ & 0 \\
Unbagged & $2.45 \pm 0.54$ & $\mathrm{~b}$ & $-{ }^{2}$
\end{tabular}

\footnotetext{
${ }^{1}$ Values with the same letters indicate that the means are not statistically different at $\mathrm{P}<0.05$.

${ }^{2}$ Unbagged fruit assessments were carried out in situ, therefore no membrane assessments were undertaken.
} 


\section{DISCUSSION}

Fruit from trees that were treated with insecticides had fewer rindspots than fruit from nil-insecticide trees. Furthermore, fruit enclosed in bags with citrus flower moth had significantly more rindspots than other fruit. Most of those rindspots had a fine semitransparent egg membrane on and many with a head capsule and body of a neonate Lepidopteran larva in a hole beneath the membrane similar to those observed in earlier field collections. These larvae were always dead, possibly indicating that the oil from the ruptured gland had killed them. Another citrus flower moth species ( $P$. citri) that is not present in New Zealand has been shown to penetrate the substrate (usually flower buds) on hatching (Mineo 1967). If this occurs on lemon fruits, the P. citri larvae pierce the oil-bearing cells and die (Mineo 1967). It is considered that this is likely to also be the case with $P$. nephelomima and the injury results in a rindspot.

There are a number of possible causes for the rupture of oil glands leading to rindspot or oleoscellosis damage. When cicadas land on fruit their tarsi can rupture an oil gland. Bruising and abrasions caused by wind or machinery can also rupture oil glands. The low incidence of rindspot observed all year round in many orchards may be due to these diverse causes. However, it has been observed that rindspot typically becomes more abundant from March-May, and in this work fruit collected in March had a high proportion of rindspots with remnants of Lepidopteran larvae associated with them. This period coincides with the peak flight activity of male citrus flower moths over the period February to April (Jamieson \& Gibb 2005). Lemon orchards have ongoing flowering, but there is often a low incidence of flowering from March to May. Young fruit have a 'rubbery' texture that is similar to flower buds, which are the usual oviposition site for citrus flower moth. Thus, the young fruit may be mistaken for suitable oviposition sites by the large number of citrus flower moth adults present at this time.

Interestingly, although there was less rindspot on fruit and fewer flowers infested with citrus flower moths in insecticide treated plots than nil-insecticide plots, the number of adults caught in pheromone traps was similar in plots of both treatments. There are a number of possible reasons why this occurred. Firstly the larvae and pupae feeding internally on floral parts were not affected by the sprays, so continued to develop to adults. However, sprays still deterred female moths from laying eggs on insecticide treated fruit or killed the eggs or newly emerged neonate larvae on the fruit. A second possible reason for little differences in trap catches between insecticide-treated and nil insecticide blocks was that pheromone traps attracted moths from both insecticide treated and nil-insecticide areas. The distance that citrus flower moths fly in a lifetime is unknown and this knowledge would assist with clarifying the reason for the lack of difference in trap catches.

Evidence from these trials indicates that neonate citrus flower moth larvae penetrating the surface of lemons after hatching are a major cause of rindspot over the period March to May in New Zealand lemon orchards.

\section{ACKNOWLEDGEMENTS}

Thanks to the MAF Sustainable Farming Fund and New Zealand Citrus Growers Incorporated for funding this work. We would also like to thank growers for allowing us to undertake trials and collections on their properties.

\section{REFERENCES}

Agrios NG 1997. Plant Pathology. 4th edition. Academic Press, California, USA. 803 pp.

Anon. 2006. Background on environmental effects during harvesting of citrus fruits. http://www.defelsko.com/applications/citrus_fruit/dpm_citrus_fruit.htm (accessed 15 May 2006). 
Gibb AR, Jamieson LE, Suckling DM, Stevens PS 2005. Sex pheromone of the citrus flower moth Prays nephelomima: pheromone identification, field trapping trials, and phenology. Journal of Chemical Ecology 31(7): 1633-1643.

Grafton-Cardwell EE, O'Connell NV, Callsen CE, Morse JG 2003. Photographic guide to citrus fruit scarring. University of California. http://anrcatalog.ucdavis.edu/pdf/8090. pdf (accessed 15 May 2006).

Jamieson LE, Gibb AR 2005. The seasonal flight activity of citrus flower moth (Prays nephelomima). HortResearch Client Report, HortResearch, Mt Albert, Auckland, New Zealand. 10 pp.

Pyle K, Harty A, Little A 2002. Research - Yen Ben lemon rind spotting. Citrus News, December: 20-21.

Timmer LW, Garnsey SM, Broadbent P 2003. Diseases of citrus. In: Ploetz RC ed. Diseases of Tropical Fruit Crops. CABI Publishing, Oxon, UK. Pp. 163-196.

Wardoski FW 1989. Physiological disorders of fruit. In: Whiteside JO, Garnesy SM, Timmer LW ed. Compendium of citrus diseases. APS Press, St Paul, Minnsota. $64 \mathrm{pp}$. 